\title{
The Barreiras Group in the Northeastern coast of the State of Bahia, Brazil: depositional mechanisms and processes
}

\author{
Geraldo S. VILAS BôAS ${ }^{1}$, FLÁVio J. SAMPaiO ${ }^{2}$ and ANTONIO M. S. PEREIRA ${ }^{2}$ \\ ${ }^{1}$ Laboratório de Estudos Costeiros - CPGG - Instituto de Geociências/UFBA \\ 41170-290 Salvador-Bahia, Brasil \\ ${ }^{2}$ Instituto de Geociências/UFBA - 41170-290 Salvador-Bahia, Brasil \\ Manuscript received on May 3, 2000; accepted for publication on May 15, 2001; \\ presented by KENITIRo SUGUIO
}

\begin{abstract}
The Barreiras Group is a Miocene to Lower Pleistocene continental terrigenous sedimentary deposit exhibiting a large occurrence along the Brazilian coast. In the Conde region, located in the northeastern part of the State of Bahia, the sedimentological characteristics of these sediments are indicative of a deposition as gravelly and sandy bed load in braided fluvial systems, related to alluvial fans, under an arid to semi-arid climate. The basal portion of the group is dominated by a gravelly-sandy lithofacies deposited by debris flows and pseudoplastic debris flows, with lesser occurrences of subaqueous deposits, characterizing a proximal fluvial system deposition. The upper portion is made up of gravelly-sandy sediments that include subaqueous, debris flows and pseudoplastic debris flows deposits. They suggest deposition in a more distal zone as indicated by the larger occurrence of subaqueous deposits and the presence, though rare, of downstream-accretion macroforms. Besides the climate control, deposition of the Barreiras Group was strongly influenced by the intraplate tectonism, which has been affecting the South America Platform since the Middle Miocene, when neotectonism began in Brazil.
\end{abstract}

Key words: Barreiras Group, Tertiary, Cenozoic, State of Bahia.

\section{INTRODUCTION}

The Barreiras Group constitutes a continental terrigenous sedimentary deposit of Miocene to Lower Pleistocene age (Jupiassu 1970, Mabesoone et al. 1972, Salim et al. 1975, Ghignone 1979, Suguio et al. 1986, Arai et al. 1988, Arai 1997, Leite et al. 1997). These sediments have widespread occurrence along the Brazilian coast, extending along the coastal zone from the northern region, as far as the State of Rio de Janeiro. Southwards, equivalent sedimentary sequences have been found as far as Uruguay (Mabesoone 1966).

Correspondence to: Geraldo S. Vilas Bôas

E-mail: gsvboas@pppg.ufba.br
The classification of the Barreiras sediments as a stratigraphic Group was first proposed by Bigarella and Andrade (1964) and later confirmed by Bigarella (1975). According to these authors, the Barreiras Group is composed by two formations, the Guararapes (basal) and Riacho Morno (top) separated by an erosional unconformity.

The geological literature on the Barreiras Group shows that most studies have focused mostly on stratigraphic and genetic aspects. Detailed information on the depositional environments and sedimentary processes are still lacking. The present work presents a study of the Barreiras Group that occurs in the northern coastal region of the State of Bahia, in the stretch between the mouths of Itariri 
and Itapicuru rivers, comprising the city of Conde (Fig. 1). Its emphasis is on the interpretation of the depositional processes and mechanisms. The existence in this area of excellent outcrops of the Barreiras Group, along highway BA-099 (Linha Verde), has made it possible for a detailed study of this sedimentary unit. The data obtained may contribute to a better understanding of the genesis of these sediments, which are related to episodes of intense erosion and deposition that affected extensive segments of the Brazilian territory during the Cenozoic.

\section{PREVIOUS PAPERS}

According to Andrade (1955) and Bigarella and Andrade (1964), the sediments composing the Barreiras Group are correlative deposits of two well marked pediplanation phases that occurred during the Cenozoic along the entire Brazilian coast. These pediplanation phases would be correlatable, as sugested by Tricart and Silva (1968), with the Cenozoic pediplanation phases of the West Africa Continental Terminal, which exhibit characteristics very similar to those of the Barreiras, as pointed out by Assemien et al. (1971). According to Klammer (1980) the depositional and erosional events from the start of the Barreiras sedimentation to the Holocene have been determined by movements of the base-level. The pediplanation phases, with their correlative deposits (Barreiras), are related to periods during which the ocean level was much lower than presently, as is evidenced by the existence of the Barreiras sediments lower sequences below present sea level. The base level oscillations gave rise to climatic cycles characterized by arid climates during lowstands and humid ones during highstands (Bigarella and Andrade 1964). Thus, the regolith developed during a humid phase was later removed to the terrain depressions during the subsequent arid/semiarid phase (Bigarella 1975) by way of debris flows and mud flows (Mabesoone et al. 1972). Emphasis should be laid on the fact that there are evidences in the Barreiras sediments of higher frequency climate changes, during which short-term increases in humidity are observed in an otherwise predominantly semi-arid epoch (Bigarella 1975).

The Barreiras sedimentation seems to be related not only to these climatic variations, but also, as pointed by Andrade and Lins (1963), Bigarella and Andrade (1964), Bigarella (1975) and Ghignone (1979), to a concurrent epeirogenic rise that goes back to the Lower Tertiary and that have created conditions for the accumulation in the downstream region of sediments produced in the drainage basins headwaters. Contemporaneous with these epirogenetic movements the occurrence of extrusive basaltic rocks (Salim et al. 1975) and small faults affecting the Barreiras Group have been reported (Bigarella 1975).

Several works have reported geological and geomorphological evidences of neotectonic activity along the coastal region of Brazil that has largely affected the sediments of the Barreiras Group (King 1956, Putzer 1959, Tricart and Silva 1968, Martin et al. 1986, Suguio and Martin 1996). According to Bittencourt et al. (1999), this neotectonic activity is associated to the development of extensional strains, resulting from the flexural deformation of the lithosphere, due to the sedimentary load deposited onto the continental margin. These strains have sufficient magnitude to promote reactivation of ancient faults and the generation of new faults.

More recently Suguio and Nogueira (1999) critically reviewed the geologic knowledge about the Barreiras sediments and stated that, notwithstanding the continental dimension of its area of occurrence, little is known about its significance regarding the global geologic events. They also emphasized the absence of stratigraphic correlation to systematize the geologic knowledge obtained throughout its whole occurrence area, and therefore considered the use of the Barreiras Formation hierarchical term instead of Barreiras Group. They also suggested the development of studies directed towards a better facies characterization together with the application of sequence stratigraphy, as a probable way to gather fundamental informations for the environmental and paleogeographic reconstructions of this sedimentary unit. They also considered that the sed- 


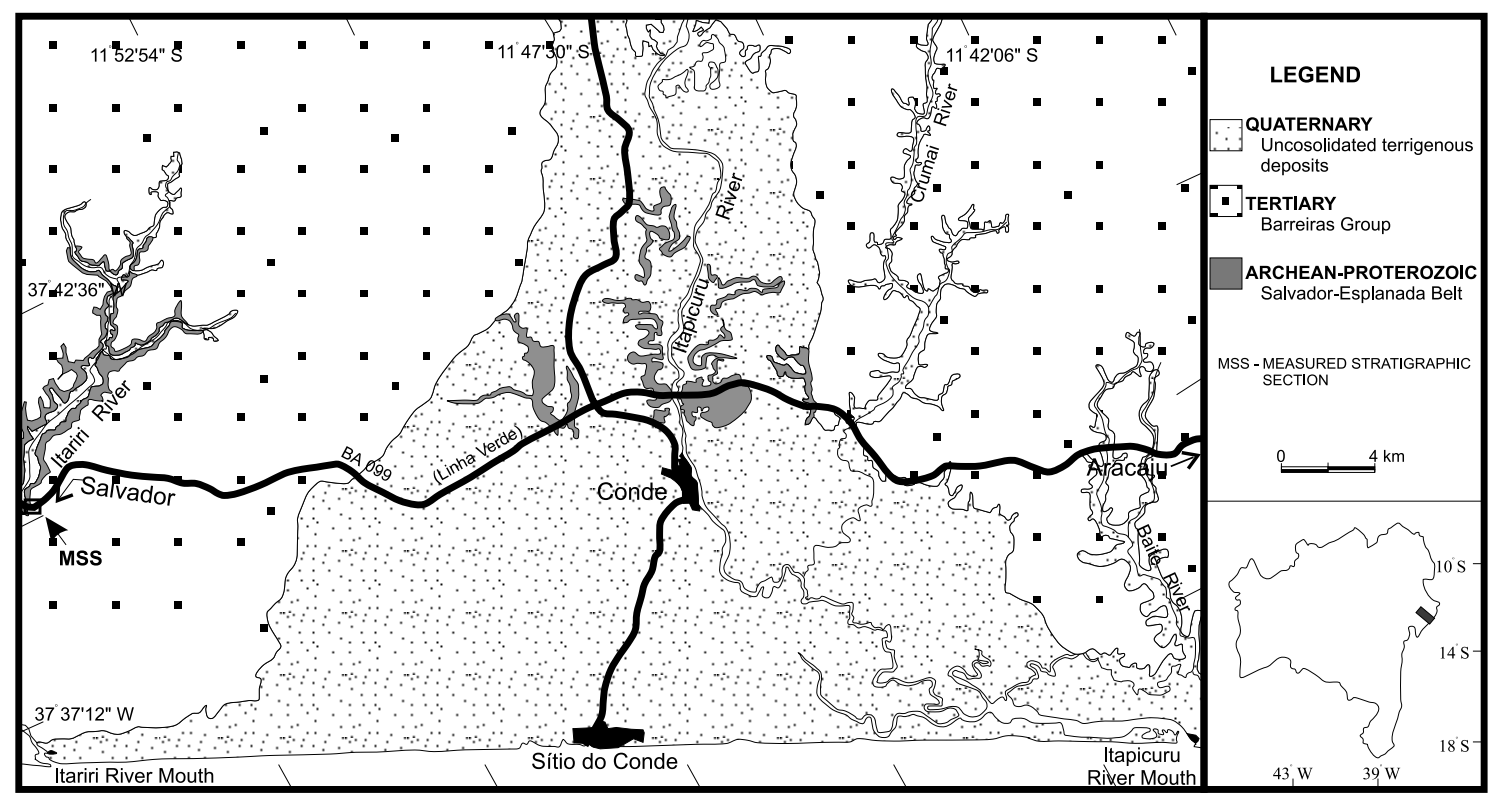

Fig. 1 - Simplified geologic and location map of the study area.

imentological and micropaleontologic studies, carried out specially in northeastern Pará State (Arai et al. 1988, Arai 1997, Leite et al. 1997) allowed a better definition of the Barreiras chronostratigraphy and suggested the development of similar studies for other areas of occurrence of the unit.

\section{GEOLOGICAL ASPECTS}

The sediments of the Barreiras Group occupy approximately $60 \%$ of the study area (Fig. 1). These sediments consist dominantly of (i) fine to coarse sands; (ii) gray-reddish, purple and yellowish clays; (iii) poorly sorted, gray-whitish, yellow and coarse to conglomeratic sandstones, with kaolinite matrix. More rarely there are polymictic conglomerates, with gneiss pebbles and milky quartz, floating in a poorly selected sandy matrix. The sands and sandstones exhibit trough and planar cross-bedding, horizontal lamination or are massive. Many times, fining-upward sequences and channel structures occur. The beds have lenticular geometry, with predominantly erosional contacts. Deposits of iron hydroxides are very common, impregnating the sandstone layers with more than one meter in thickness.
The muddy and clayey levels are massive or finely laminated. They are generally lenticular, with a thickness of less than $50 \mathrm{~cm}$. Less frequently there occur thicker beds with tabular geometry and larger lateral extension. Locally, the unit is covered by quartzose sand deposits of white to greyish color. These sands are products of pedogenesis and correspond to podzol type soils (Ribeiro 1998).

In the study area, measured stratigraphic section indicates that the thickness of the Barreiras Group reaches aroud 30m (Fig. 2). Similar thicknesses were obtained based on geophysical profiling (electro-resistivity) data and some wells drilled by the Companhia de Engenharia Rural da Bahia (CERB 1973).

In the study area, the Barreiras sediments lie unconformable upon the Salvador-Esplanada Belt rocks of Archean-Lower Proterozoic age (Barbosa et al. 1996). Sedimentary terrigenous continental and marine deposits of Quaternary age are also present in the study area, resting unconformably on the Barreiras Group and the rocks of the Salvador-Esplanada belt (Bittencourt et al. 1979, 1996) (Fig. 1). 


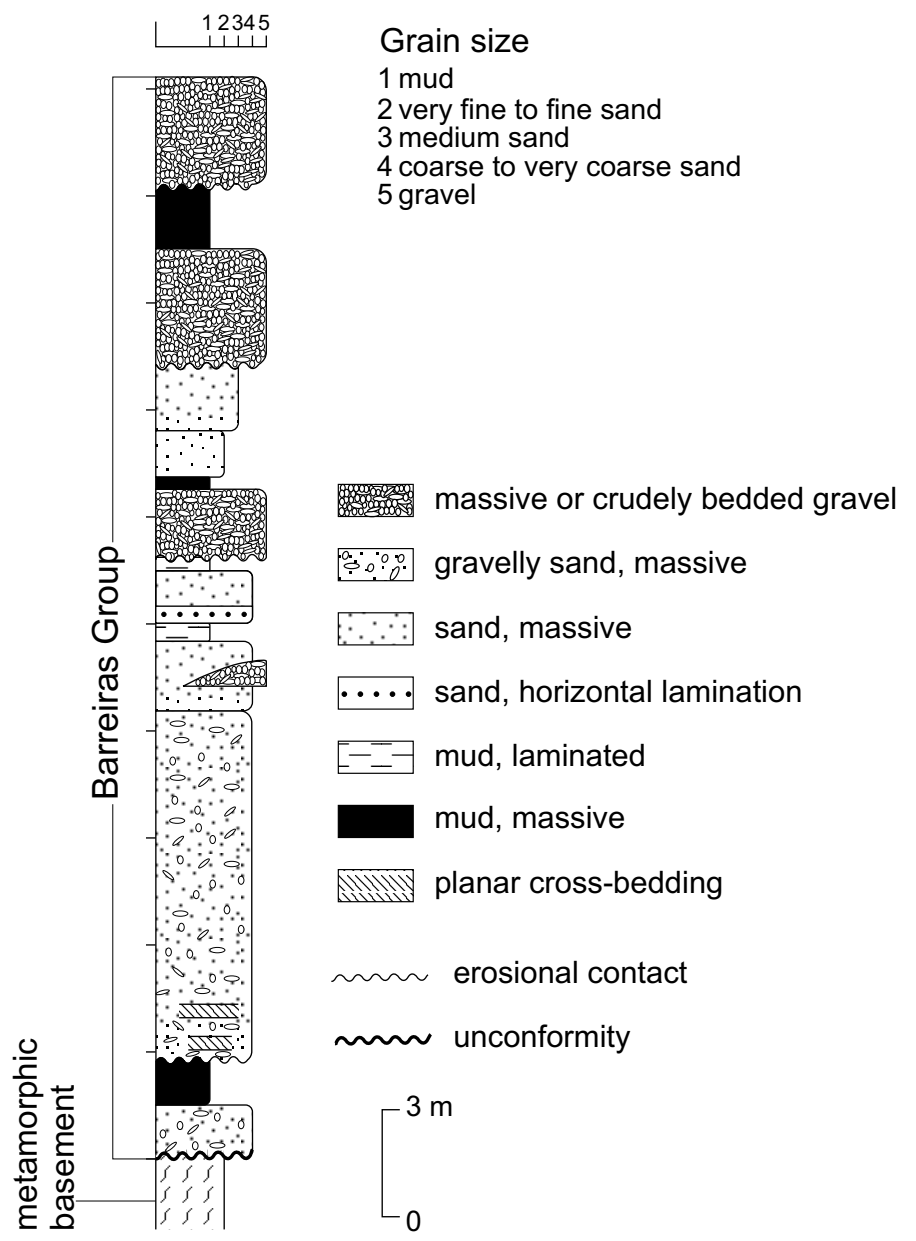

Fig. 2 - Measured stratigraphic section on Barreiras Group at the extreme south region of the study area (for location see Figure 1).

In the study area, the main evidence of neotectonic activity is represented by the presence of fractures sporadically found in outcrops of the Barreiras Group. These fractures are arranged in two main systems with directions $\mathrm{N} 60^{\circ} \mathrm{E}$ and $\mathrm{N} 35^{\circ} \mathrm{W}$. The drainage system of the area exhibits a parallel to subparallel pattern that reflects a tectonic control related to these fracture systems.

\section{DEPOSITIONAL PROCESSES}

Based on interpretation of the sedimentological characteristics, the deposits forming the Barreiras Group, were grouped into three different types, namely: 1) debris flow deposits; 2) pseudoplastic debris flow deposits; 3) subaqueous deposits.

\section{Debris Flow Deposits}

These deposits include gravelly and sandy-gravelly massive bedded sediments, supported by a sandymuddy and/or muddy matrix (Fig. 3A). They occur in beds with tabular geometry, and thickness varying from tens of centimeters to some tens of meters. In general, thicker beds are formed by individual amalgamated beds, separated by abrupt contacts, or by intercalated gravelly levels (Fig. 3B). The massive character and the random distribution 
of the large fragments in the finer matrix indicate a deposition by debris flows (Middleton and Hampton 1976) or by plastic debris flows (as named by Shultz 1984). These processes have also been named highconcentration cohesive dispersions (Fisher 1971), or cohesive debris flows (Lowe 1982). During transport, the clasts are maintained suspended by the buoyancy effect favored by the high cohesion of the water-sediment mixture composing the matrix (Hampton 1979). Deposition occurs when the mass strength equals the shearing intensity promoting the flow, resulting in immobilization of same, in a process designated as cohesive freezing (Lowe 1982). This may result from a declivity decrease and/or from a decrease in the flow water content.

\section{Pseudoplastic Debris Flow Deposits}

In this category are included gravelly deposits supported by a sandy matrix and sandy-gravelly massive deposits, interpreted as pseudoplastic debris flow deposits (Shultz 1984) (Fig. 4). The clasts are randomly dispersed in the sandy matrix and many of them present themselves with the larger axes arranged vertically. The conglomeratic and sand-conglomeratic bodies exhibit thicknesses varying from tens of centimeters in individual beds up to some tens of meters in amalgamated beds. These bodies present tabular or channel geometries. The massive bedding, the presence of clasts with the larger axis arranged in the vertical, the absence or the small amount of mud in the matrix and the channel geometry, as observed in many occurrences of this type of deposit, point towards a deposition by pseudoplastic debris flows. This type of flows is characterized by a low elastic limit due to a relatively high water content, which results in a relatively low cohesion, as compared to the debris flow (Shultz 1984). The greater dilution also results in a lesser matrix strength, insufficient to support the clasts. Thus, the support of the latter is promoted by dispersive pressure mechanisms, that is more active in locations with larger concentration of clasts, and turbulence, which develops in the stage where the flow velocity is higher.

\section{Subaqueous Deposits}

In this category are included gravelly and sandy deposits resulting from deposition by stream flow at various flow regimes as well as muddy deposits of vertical accretion nature.

Stream flow deposits - These deposits are represented by layers of sandy, sandy-gravel and gravelly sediments presenting sedimentary structures resulting from development and migration of subaqueous bedforms. In this group dominate sandy layers with trough cross-bedding, resulting from the migration of 3-D (tridimensional) type subaqueous dunes (Ashley 1990), which generally occur, forming cosets, whose thicknesses may reach some tens of meters. Very rarely centimetric to decimetric levels of sands with horizontal lamination are observed, resulting from the deposition on upper flow flat-bed regime, or cosets with planar cross-bedding, produced by the migration of 2-D type subaqueous dunes (Ashley 1990). Very rare occurrences of gravelly and sandy-gravelly deposits, with horizontal poorly developed stratification, were also present.

Vertical accretion deposits - These deposits comprise red, yellow, gray and variated colored, massive and very seldom laminated muds. Mostly they appear as thin beds or lenses of millimetric to decimetric thicknesses, intercalated in the coarse-grained deposits. Laterally, they may have extensions from a few centimeters to some hundreds of meters. Possibly they represent either overbank sediments deposited during high-water stages or the products of deposition in depressions on the sandy-gravelly bodies during low-water periods following floods. Less commonly, there has been observed muddy bodies with thickness up to $3 \mathrm{~m}$, which may extend laterally some hundreds of meters or even some kilometers. These are interpreted as extensive overbank or lake deposits.

\section{DISCUSSION AND CONCLUSIONS}

The sedimentary characteristics of the Barreiras Group in the study area indicate a deposition predominantly as sandy-gravelly bed loads in braided 

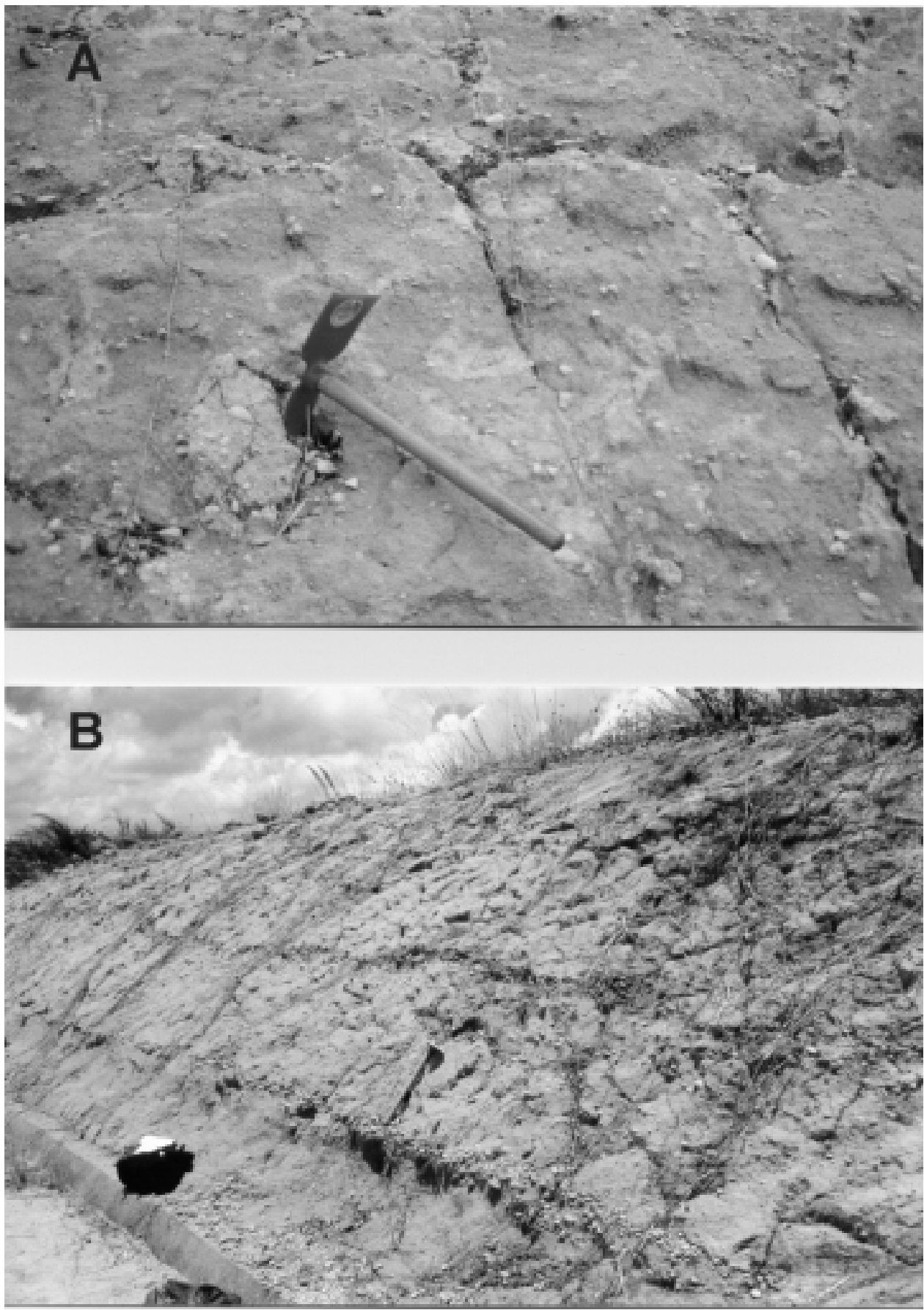

Fig. 3 - Debris flow deposits. A: observe the massive character of the bedding and the random distribution of the larger clasts in a muddy matrix. B: individual layers, separated by gravel levels. Barreiras Group outcrop on highway BA-099 (Linha Verde). 


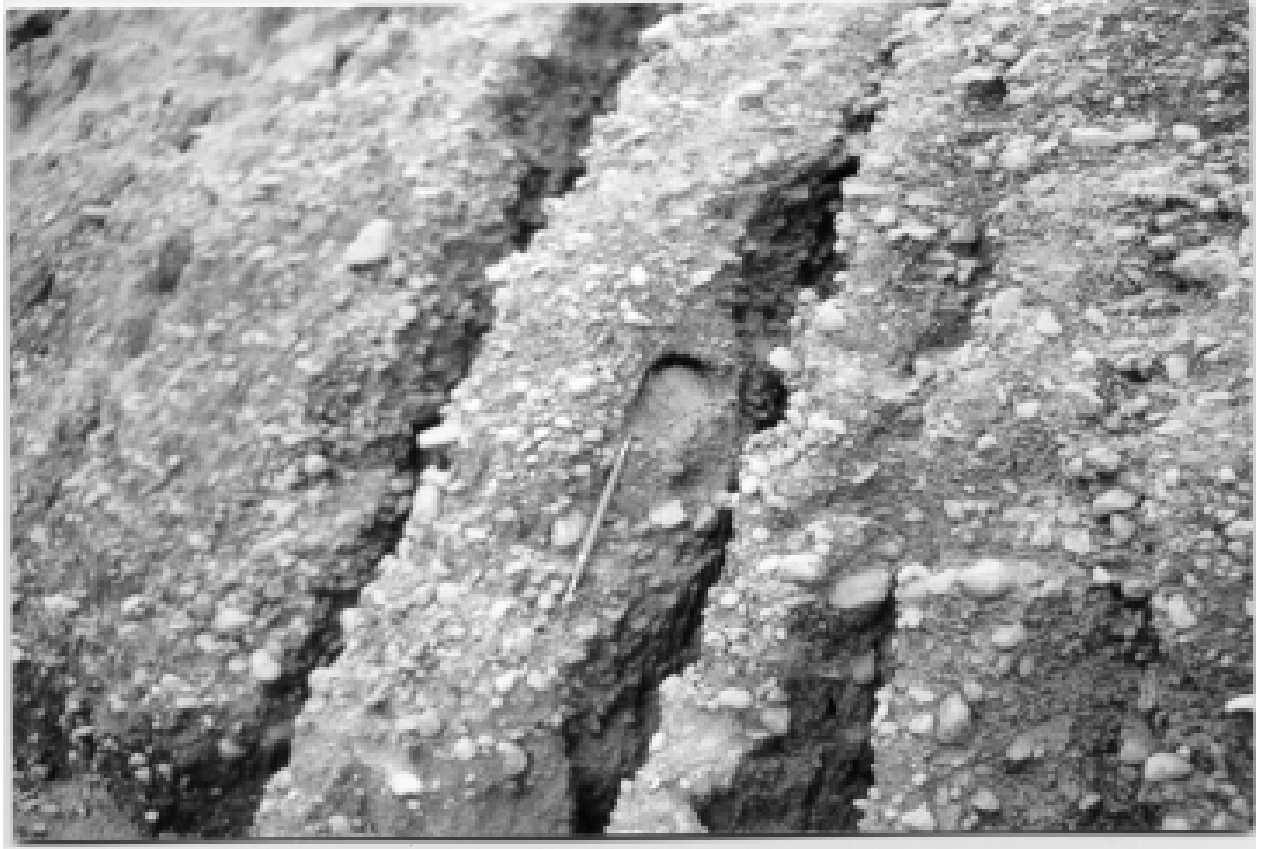

Fig. 4 - Pseudoplastic debris flow deposits. Observe the massive character of the deposit and the random distribution of the larger clasts immersed in a sandy matrix. Barreiras Group outcrop on highway BA-099 (Linha Verde).

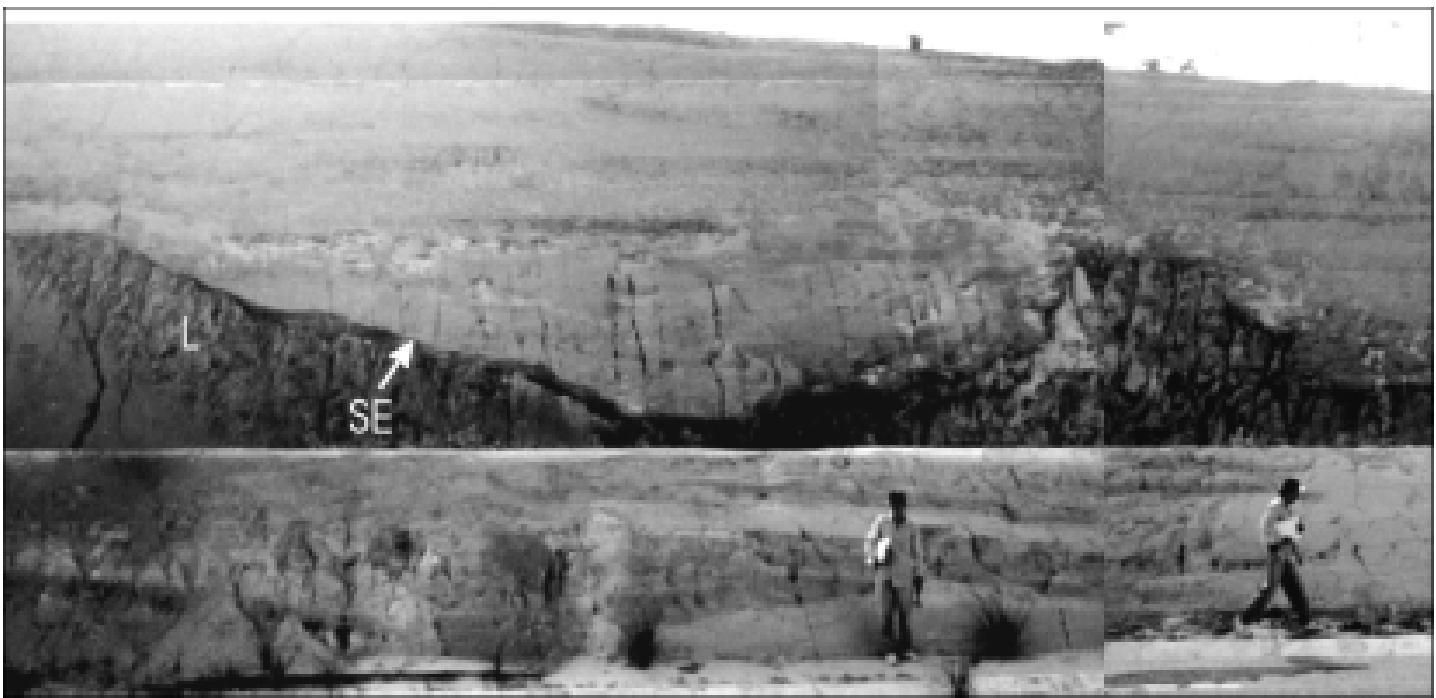

Fig. 5 - Erosion surface (SE), extensively cut by channels, separating the Barreiras Group basal and upper portions. Observe muddy deposit (L) on top of the basal portion. Outcrop on highway BA-099 (Linha Verde). 
fluvial systems related to alluvial fans, under arid to semi-arid climate. This interpretation corroborates previous works done on the Barreiras Group along the brazilian coastal zone (e.g. Mabesoone et al. 1972, Bigarella 1975, Alheiros et al. 1988). On the other hand, no occurence of facies indicative of marine or transitional environments were found in the study area as have been reported by Arai et al. (1988), Arai (1997) and Leite et al. (1997), for the Barreiras Group sediments occurring in northeastern state of Pará.

The deposits of the Barreiras Group in the study area were tentatively subdivided into two informal units, lower and upper, separated by an erosional contact. Detailed strratigraphic studies, including other areas of occurrence of the Barreiras Group along the coastal zone of the State of Bahia, are still necessary in order to determine the local or regional character of this erosional unconformity. This definition is very important in order to establish a possible correlation of the stratigraphic units identified in this study with the Guararapes and Riacho Morno formations described by Bigarella (1975).

The more basal part of the lower unit is dominated by sandy-gravelly lithofacies deposited by debris flows, with lesser occurrence of subaqueous deposits, characterizing a deposition in more proximal regions. In some outcrops, these sediments are covered by a muddy layer with a thickness of up to $3 \mathrm{~m}$, forming the upper part of the unit. The deposition of this layer has probably occurred in a ephemerous lacustrine depositional environment. The top of the lower unit is truncated by an erosional surface, extensively cut by channels, separating it from the upper unit (Fig. 5).

The upper unit is formed by sandy-gravelly sediments that include subaqueous, debris flow and pseudoplastic debris flow deposits. Although, texturally similar to the lower unit, this upper unit, has been deposited, appparently in a more distal portion than those of the lower unit. This interpretation is based on a greater occurrence in this upper unit of aqueous flow deposits and the presence, though rare, of downstream accretion macroforms (Miall 1988), representing complex bar deposits more characteristic of these distal regions. In the macroform seen on Figure 6 ( $\mathrm{A}$ and $\mathrm{B})$, the accretion surfaces $\left(3^{\text {rd }}\right.$ order surfaces of Miall 1988) dip in the N30 E sense, indicating a northeastward migration direction. Additional studies are necessary to determine if the differences between the upper and the lower units are the result of alloctonous or autoctonous controls.

The sedimentological characteristics of the Barreiras Group, consisting dominantly of sandy and gravelly sediments, and the processes responsible for their deposition, besides reflecting arid to semi-arid climate conditions, are also indicative of the influence of tectonism in the genesis of these deposits. In fact, the establishment of a depositional context dominated by alluvial fans and braided rivers with sand-gravelly bedload implies steep reliefs resulting from tectonic action (Miall 1981, 1996). This interpretation agrees with the work done by Hasui (1990), who suggests that the Barreiras sedimentation is strongly conditioned by a tectonic episode which resulted in reactivation of ancient faults, related to crustal weakness zones, the origins of which date back to the Lower Proterozoic. Still according to that author, this episode probably started in the Middle Miocene and establishes the begining of the neotectonic activity in Brazil.

\section{RESUMO}

O Grupo Barreiras é uma cobertura sedimentar terrígena, de idade Miocênica a pleistocênica inferior, que tem grande ocorrência ao longo do litoral brasileiro. Na região de Conde, localizada na porção nordeste do Estado da Bahia, as características sedimentológicas desses depósitos são indicativas de uma deposição por sistemas fluviais de padrão entrelaçado, com carga de leito arenocascalhosa, associados a leques aluviais, em condições de clima árido a semi-árido. A porção basal do grupo é dominada por litofácies areno-cascalhosas depositadas por fluxos de detritos e fluxos de detritos pseudoplásticos, com uma ocorrência menor de depósitos de fluxo subaquoso, caracterizando uma deposição em um sistema fluvial proximal. A porção superior é composta por sedimentos areno-cascalhosos que incluem depositos subaquosos, 

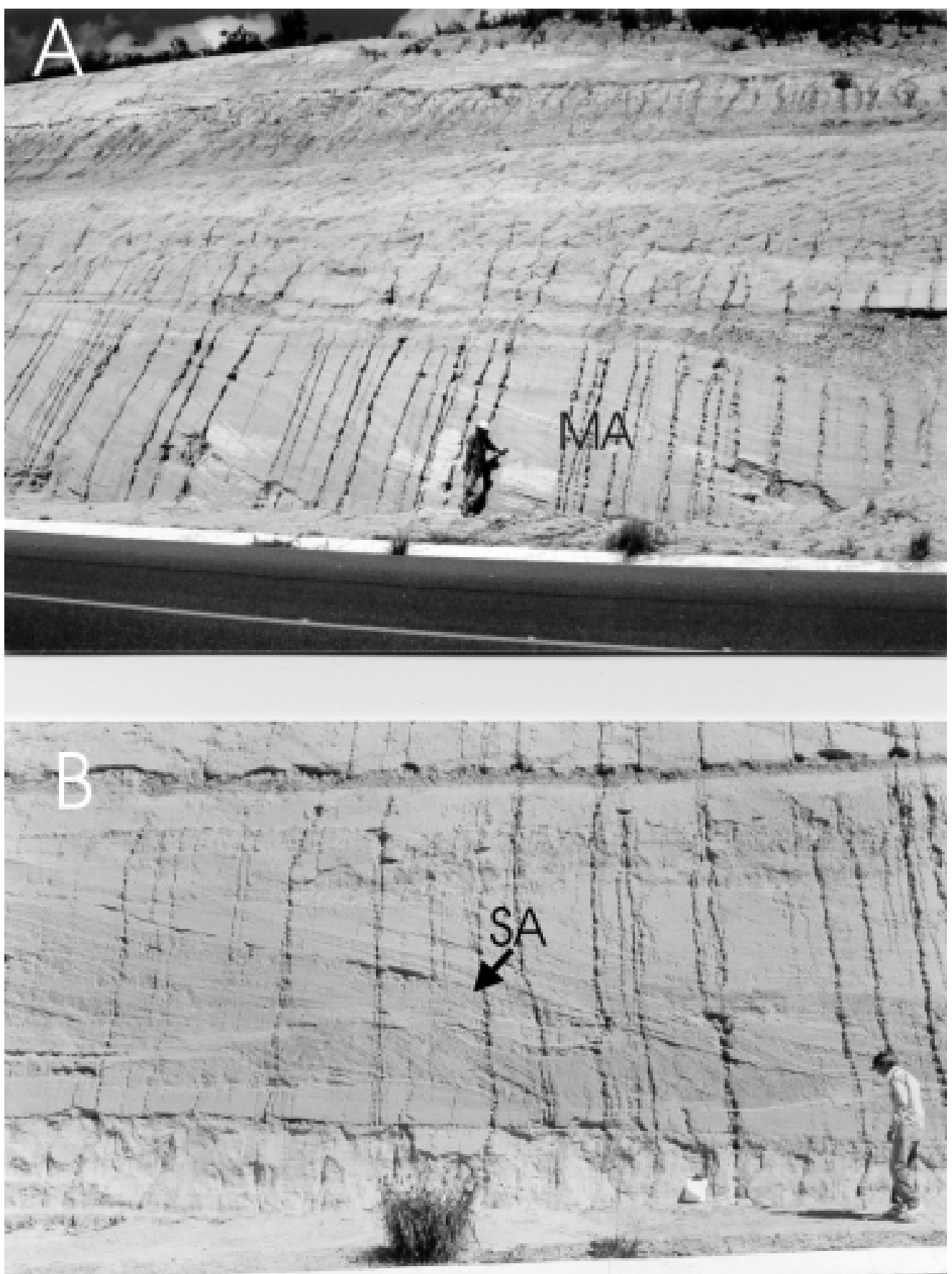

Fig. 6 - A: Downstream accretion macroform (MA) in the lower portion of the photograph, showing the accretion surfaces dipping rightwardly (northeast). B: detail of an accretion surface (SA). Barreiras Group outcrop on highway BA-099 (Linha Verde). 
de fluxos de detritos e de fluxos de detritos verdadeiros. As características desses depósitos sugerem uma deposição em um contexto deposicional mais distal, em relação à porção basal do grupo, inferido por uma maior ocorrência de depósitos de fluxo aquoso e pela presença, ainda que rara, de macroformas de acrescimento para jusante. Além do controle climático, a deposição do Grupo Barreiras foi fortemente influenciada pelo tectonismo intraplaca, que vem afetando a plataforma sul-americana a partir do Mioceno Médio e que marca o início da ação neotectônica no Brasil.

Palavras-chave: Grupo Barreiras, Terciário, Cenozóico, Estado Bahia.

\section{REFERENCES}

Alheiros MM, Lima Filho MF, Monteiro FAJ AND OliveIra Filho JS. 1988. Sistemas deposicionais na Formação Barreiras no Nordeste Oriental. In: Congresso Brasileiro de Geologia, 35. Belém. Anais... Belém. SBG. 1988. v.2. p. 753-760.

Andrade GO. 1955. Itamaracá. Contribuição para o estudo geomorfológico da costa pernambucana. Recife, Pernambuco, Imprensa Oficial. 87 p.

AndRAdE GO AND Lins RC. 1963. O conglomerado do baixo Pirapama. Recife, Pernambuco, Caderno da Faculdade de Filosofia de Pernambuco, N², Imprensa Universitária.

Arai M. 1997. Dinoflagelados (Dinophyceae) miocênicos do Grupo Barreiras no nordeste de Estado do Pará (Brasil). Guarulhos: Revista Universidade Guarulhos, Geociências II ( ${ }^{\circ}$ especial): 98-106.

Arai M, Uesugui N, Rosseti DF and Goes AM. 1988. Considerações sobre a idade do Grupo Barreiras no nordeste do Estado do Pará. In: Congresso BraSileiro de Geologia, 35. Belém. Anais... Belém. SBG. 1988. v.2. p. 738-750.

Ashley GM. 1990. Classification of large-scale subaqueous bedforms: a new look at an old problem. J Sed Petrol 60: 160-162.

Assemien P, Filleron JC and Tastet JR. 1971. Le Quaternaire de la zone littorale de côte d'Ivoire. Quaternária XV: 305-310.
Barbosa JSF, Sabaté P And Dominguez JML. 1996. O estado da Bahia na Plataforma Sul-Americana, suas subdivisões, critérios de empilhamento estratigráfico das coberturas plataformais e ciclos geotectônicos. In: BARbosa JSF AND Dominguez JML (Ed.); Mapa Geológico do Estado da Bahia - Texto Explicativo. Salvador, Bahia: Secretaria das Minas e Energia/SGM. p. 41-61.

Bigarella JJ. 1975. The Barreiras Group in Northeastern Brazil. An Acad Bras Ci 47 (suplemento): 366-392.

Bigarella JJ AND Andrade GO. 1964. Considerações sobre a estratigrafia dos sedimentos cenozóicos em Pernambuco (Grupo Barreiras). Recife: Universidade de Recife, Arq. Inst. Ciênc. Terra 2: 2-14.

Bittencourt ACSP, Martin L, Vilas Boas GS and FLEXOR JM. 1979. The marine quaternary formations of the coast of the state of Bahia (Brazil). In: Suguio K et al. (Ed.); Proceedings of the " 1978 International Symposium on Coastal Evolution in the Quaternary',. São Paulo: p. 232-253.

BitTencourt ACSP, LeÃo ZMAN, Vilas BoAs GS AND Brichta A. 1996. Quaternário-Holoceno, Quaternário-Pleistoceno e Terciário. In: BARBOSA JSF AND Dominguez JML (Ed.); Mapa Geológico do Estado da Bahia - Texto Explicativo. Salvador, Bahia: Secretaria das Minas e Energia/SGM. p. 263-268.

Bittencourt ACSP, Dominguez JML and Ussami N. 1999. Flexure as a tectonic control on the large scale geomorphic characteristics of the eastern brazilian coastal zone. J of Coastal Res 15: 505-519

CERB. 1973. Cadastro de poços-CERB1. Salvador: Companhia de Engenharia Rural da Bahia, Secretaria de Recursos Hídricos.

FiSHER RV. 1971. Features of coarse-grained, high-concentration fluids and their deposits. J Sed Petrol 41: 916-927.

Ghignone JI. 1979. Geologia dos sedimentos fanerozóicos do Estado da Bahia - Textos Básicos, v.1. Salvador, Bahia: Secretaria de Minas e Energia/CPM. p. 24-117.

Hampton MA. 1979. Buoyance in debris flow. Jour Sed Petrol 49: 753-758. 
HAsui Y. 1990. Neotectônica e aspectos fundamentais da tectônica ressurgente no Brasil. Bol Soc Bras Geologia - Núcleo de Minas Gerais 11: 1-31.

Jupiassu MAS. 1970. Madeira fóssil huminiácea de Intuia, Estado do Pará. Bol. Museu Paraense Emílio Goeldi (Geologia 14): 1-12.

KING LC. 1956. A geomorfologia do Brasil Oriental. Rev Bras Geografia 2: 37-72.

Klammer G. 1980. Amazonian Plio-Pleistocene sedimentation and morphogenesis in the diagenetic environment of high alumina clays and rocks. Intern. Assoc. Sedimentologists $1^{\text {st }}$ Europe MTG Bochum (abstract).

Leite FPR, Bernardes-De-Oliveira ME, Arai M And Truckenbrodt W. 1997. Palinoestratigrafia da Formação Pirabas e Grupo Barreiras, Mioceno do nordeste do Estado do Pará, Brasil. Guarulhos: Revista Universidade Guarulhos, Geociências II ( $n^{\circ}$ especial): 141-147.

Lowe DR. 1982. Sediment gravity flows: II. Depositional models with special reference to the deposits of high-density turbidity currents. J Sed Petrol 52: 279-297.

Mabesoone JM. 1966. Relief of northeastern Brazil and its correlated sediments. Zietschr Geomorph 10: 419-453.

Mabesoone JM, Campos E, Silva A and Beurlen K. 1972. Estratigrafia e origem do Grupo Barreiras em Pernambuco, Paraíba e Rio Grande do Norte. Rev Bras Geoc 2: 173-190.

Martin L, Bittencourt ACSP, Flexor JM, Suguio K AND Dominguez JML. 1986. Neotectonic movements on a passive continental margin: Salvador region, Brazil. Neotectonics 1: 87-103.

Miall AD. 1981. Alluvial sedimentary basins: tectonic setting and basin architecture. In: Miall AD (Ed.); Sedimentation and tectonics in alluvial basins. Geol Assoc Can Spec Paper 23: 1-33.

Miall AD. 1988. Architectural element and bounding surfaces in fluvial deposits: anatomy of the Kayenta formation (Lower Jurassic), southwest Colorado. Sediment Geol 55: 233-262.
Miall AD. 1996. The Geology of Fluvial Deposits: Sedimentary facies, Basin Analysis and Petroleum Geology. Berlin, Heidelberg, New York: SpringerVerlag, $582 \mathrm{p}$.

Middleton GV and Hampton MA. 1976. Subaqueous sediment transport and deposition by sediment gravity flows. In: STANLEy DJ AND SwIFT DJP (Ed.); Marine transport and environmental management. New York: J. Wiley. p. 197-218.

Putzer H. 1959. Movimentos quaternários epirogênicos da costa sudeste do Brasil e o problema do sambaqui. Campinas: Universidade de Campinas - Faculdade de Filosofia, Ciências e Letras - Departamento de Geografia, Notícia Geomorfológica 2: 39-41.

Ribeiro LP. 1998. Os Latossolos Amarelos do Recôncavo Baiano: gênese, evolução e degradação. Salvador, Bahia: Fundação de Apoio à Pesquisa e Extensão - FAPEX. 99 p.

Salim J, Souza CJ, Muniz GCB and Lima MR. 1975. Novos subsídios para a elucidação do episódio "Barreiras" no Rio Grande do Norte. In: Simpósio DE Geologia do Nordeste, 7. Fortaleza. Atas... Fortaleza, SBG. 1975. p. 149-158.

Shultz AW. 1984. Subaerial debris flow deposition in the Upper Paleozoic Cutler Formation, Western Colorado. J Sed Petrol 54: 759-772.

Suguio K And Martin L. 1996. The role of neotectonics in the evolution of the Brazilian coast. Geonomos 4 : 45-53

Suguio K AND NogueIRA ACR. 1999. Revisão crítica dos conhecimentos geológicos sobre a Formação (ou Grupo?) Barreiras do Neógeno e o seu possível significado como testemunho de alguns eventos geológicos mundiais. Geociências, São Paulo 18: 461479.

Suguio K, Bidegan JC and Morner NA. 1986. Dados preliminares sobre as idades paleomagnéticas do Grupo Barreiras e da Formação São Paulo. Rev Bras Geoc 16: 171-175.

Tricart J AND Silva TC. 1968. Estudo da Geomorfologia da Bahia e Sergipe. Salvador, Bahia: Fundação para o Desenvolvimento da Ciência na Bahia. 167 p. 